Www.jmscr.igmpublication.org

Impact Factor (SJIF): 6.379

Index Copernicus Value: 79.54

ISSN (e)-2347-176x ISSN (p) 2455-0450

crossrefDOI: https://dx.doi.org/10.18535/jmscr/v6i8.205

Journal Of Medical Science And Clinical Research

IGM Publication

An Official Publication of IGM Publication

\title{
A Study of Serum Lactate Dehydrogenase and Uric Acidlevel in Pre- Eclampsia in a Tertiary Health Care Centre in North-East India
}

\author{
Authors
}

\author{
Moumita Saha ${ }^{1}$, S.M. Rohman ${ }^{2}$, K.K Das ${ }^{3}$
}

${ }^{1}$ MD Biochemistry, Dept of Biochemistry, Gauhati Medical College \& Hospital, Guwahati, Assam, India ${ }^{2}$ MD Biochemistry, Associate Professor, Department of Biochemistry, Gauhati Medical College \& Hospital, Guwahati, Assam, India

${ }^{3}$ MS Obs \& Gynae, Associate Professor, Department of Obs \& Gynae, Gauhati Medical College \& Hospital, Guwahati, Assam, India

Corresponding Author

\section{Moumita Saha}

MD Biochemistry, Dept of Biochemistry, Gauhati Medical College \& Hospital, Guwahati, Assam, India

\begin{abstract}
:
Introduction: Pre-Eclampsia is a multi-system disorder of unknown aetiology, unique to pregnancy, onset after 20 weeks of gestation with hypertension to the extent of 140/90 $\mathrm{mm} \mathrm{Hg}$ or more, and proteinuria ( $\geq 300 \mathrm{mg} /$ day) and edema. FOGSI (The Federation of Obstetric \& Gynaecological Societies of India) and other studies show the incidence of Pre-Eclampsia in India ranges between 11-13\%. And in North-East region of India it is very much common. NFHS has been conducted in India for three successive rounds. Among states highest prevalance found in Tripura (87.5\%) and lowest prevalance state Haryana (33.3\%). Lactate Dehydrogenase (LDH) is mainly an intracellular enzyme. It is responsible for interconversion of pyruvate and lactate in the cells. Its levels are several times greater inside the cells than in the plasma. LDH levels are increased in the scenario of increased cell leakiness, hemolysis and cell death. Pre-Eclampsia is a multisystem disorder and leads to a lot of cellular death. So, serum LDH levels can be used to assess the extent of cellular death and thereby the severity of disease. Uric Acid is a catabolic product of purine Nucleotide. Hyperuricemia is found to be one of the largest laboratory manifestations of PreEclampsia. It is likely to be resulted from reduced Uric Acid clearance from reduced glomerular filtration rate and reduced tubular secretion. Hence, Serum LDH Levels and Uric Acid can be used as tool in making decision, regarding the management strategies to improve the maternal and fetal outcome.

Materials and Methods: The subjects for the study were divided into 3 groups:

Group I-Control groups $=60$ normal pregnant women of $>20$ weeks of gestation, age between 18 to 35 years.

Group II - Case group $1=30$ newly diagnosed cases of Mild Pre-Eclampsia women of $>20$ weeks of gestation, age between 18 to 35 years.

Group III - Case group $2=30$ newly diagnosed cases of Severe Pre-Eclampsia women of >20weeks of gestation, age between 18 to 35 years.

Results: To compare Serum LDH levels in normal pregnant women and in women with Pre-Eclampsia. To compare Serum Uric Acid levels in normal pregnant woman and in woman with Pre-Eclampsia. To find out any possible correlation of their levels with the severity of the disease.

Conclusion: On the basis of our results we conclude the study that, there is a significant elevation of Serum LDH and Uric Acid in both Mild Pre-Eclampsia and Severe Pre-Eclampsia patients compared to normal pregnant women. Increased levels of Serum LDH and Uric Acid acts as efficient biomarkers for early diagnosis of Pre-Eclampsia and its subsequent course of the disease. So, Serum LDH Levels and Uric Acid can be used as tool in making decision, regarding the management strategies to improve the maternal and fetal outcome.
\end{abstract}

Keywords: Mild and Severe Pre-Eclampsia, LDH, Uric acid. 


\section{Introduction:}

Pregnancy is a physiological state associated with many alterations in metabolic, biochemical, physiological, haematological and immunological processes. If there are no complications, all these changes are reversible following a few days to a few months after delivery. ${ }^{1}$ Hypertensive disorders of pregnancy and their complications rank as one of the major cause of maternal mortality and morbidity in the world. ${ }^{2,3,4}$ It accounts for approximately a quarter of all antenatal admissions. In addition, as it is strongly associated with fetal growth retardation and prematurity, it also contributes largely to perinatal mortality and morbidity. ${ }^{5}$

Pre-Eclampsia is a multi-system disorder of unknown aetiology, unique to pregnancy, onset after 20 weeks of gestation with hypertension to the extent of $140 / 90 \mathrm{~mm} \mathrm{Hg}$ or more, and proteinuria ( $\geq 300 \mathrm{mg} /$ day) or $\geq 1+$ dipstick. $^{6}$

Pre-Eclampsia subdivided into -

1. Mild Pre-Eclampsia: ${ }^{6}$ Defined as Pregnant female of $>20$ weeks of gestation with blood pressure $\geq 140 / 90 \mathrm{~mm}$ of $\mathrm{Hg} \&<160 / 110 \mathrm{~mm}$ of $\mathrm{Hg}$ noted first time during pregnancy on $\geq 2$ occasions at least 6 hours apart with proteinuria of $\geq 1+(\geq 30 \mathrm{mg} / \mathrm{dl})$ by dipstick method in a random urine sample would be considered as having mild Pre-Eclampsia after excluding urinary tract infection.

2. Severe Pre-Eclampsia: ${ }^{6}$ Defined as the presence of 1 of the following symptoms or signs-

- SBP of $160 \mathrm{~mm} \mathrm{Hg}$ or higher or DBP of $110 \mathrm{~mm} \mathrm{Hg}$ or higher on 2 occasions at least 6 hours apart while the patient is in bed rest.

- Proteinuria of $5 \mathrm{gm}$ or higher in a 24-hour urine specimen or $3+$ or greater on two random urine samples collected atleast 4 hours apart $3+$ on 2 random urine samples collected at least 4 hours apart within 7 days.

- Oliguria of less than $500 \mathrm{ml}$ in 24 hours.

- Impaired Liver function.
- Thrombocytopenia (platelets <100000 cells/micro lit of blood).

- Intrauterine growth restriction.

Without intervention, Pre-Eclampsia progresses to Eclampsia, this is characterized by malignant hypertension and epileptiform convulsions requiring emergency caesarean section. ${ }^{7}$

Pre-Eclampsia complicates $2-8 \%$ of pregnancies and is a major cause of maternal morbidity, perinatal mortality \& morbidity and premature delivery. ${ }^{7,8}$

The worldwide incidence of Pre-Eclampsia varies greatly and it ranges between $2 \%$ and $10 \%$ of pregnancies. WHO estimated the incidence of PreEclampsia to be seven times higher in developing countries $(2.8 \%$ of live births) than in developed countries $(0.4 \%) .{ }^{9}$ It accounts for approximately a quarter of all antenatal admissions. ${ }^{10}$

India's third National Family Health Survey (NFHS-3, 2005-06) collected data from 124385 women residing in 109041 households. ${ }^{11}$ The findings for prevalence of Pre-Eclampsia by India's state and rural/urban residence. More than half of the respondents $(n=22061 ; 55.6 \%)$ had reported symptoms of Pre-Eclampsia. Almost similar prevalence for Pre-Eclampsia was found in rural $(56.2 \%)$ and urban (54\%) India though higher rates $(>70 \%)$ were observed in the states of Uttarakhand, Bihar, Jharkhand, Kerala with the highest being in Tripura (87.5\%) and lowest prevalence State (Haryana-33.3\%). ${ }^{12}$

Lactate Dehydrogenase (LDH) is mainly an intracellular enzyme. It is responsible for interconversion of Pyruvate and Lactate in the cells. Its levels are several times greater inside the cells than in the plasma.

Serum LDH value above the reference range is taken as raised. So its levels are increased in the scenario of increased cell leakiness, hemolysis and cell death. ${ }^{13}$

Pre-Eclampsia is a multisystem disorder and leads to a lot of cellular death. So, serum LDH levels can be used to assess the extent of cellular death and thereby the severity of disease. ${ }^{14,15,16}$ 
Uric Acid is a catabolic product of purine Nucleotide. It's filtrated through glomeruli and almost completely reabsorbed in proximal convoluted tubules by both active and passive carrier mediated Process. It is also actively secreted into the tubules. $85 \%$ of total excreted UA is derived by tubular secretion. ${ }^{17}$ Hyperuricemia is found to be one of the largest laboratory manifestations of Pre-Eclampsia. ${ }^{18}$

Serum Uric Acid value above the reference range is taken as raised. It is likely to be resulted from reduced uric acid clearance from reduced glomerular filtration rate and reduced tubular secretion. Its increased levels suggest serious impending damage to kidney functions. ${ }^{19}$

As of date, studies on Serum LDH Levels and Uric Acid levels in patients with Pre-Eclampsia has not been carried out sufficiently in the NorthEast region of India. Hence Serum LDH Levels and Uric Acid can be used as tool in making decision, regarding the management strategies to improve the maternal and fetal outcome in the patients with Pre-Eclampsia in this part of the country and will also help the clinician in formulating treatment protocol in such patients.

Several studies have been carried out till date to understand the pathophysiological basis of this disease. But still the exact pathophysiology of this disease is not known. Impaired trophoblast invasion leading to atherosclerotic lesions in placenta is implicated as a causal factor in pathogenesis of the disease. ${ }^{20}$ Many other theories such as endothelial dysfunction caused by factors released from ischemic placenta, ${ }^{21}$ immunological intolerance between maternal and fetal tissues, genetic predisposition, nutritional imbalance, oxidative stress are also postulated. ${ }^{22,23}$

\section{Methods and Materials \\ Place of Work}

The present study was conducted in the Department of Biochemistry and the Department of Obstetrics \& Gynaecology, Gauhati Medical College \& Hospital, Guwahati.

Period of Work August 2015 to July 2016.

\section{Plan of Study}

\section{Inclusion criteria}

The Study was conducted in three broad groups:

a) Control groups $=60$ normal pregnant women of $>20$ weeks of gestation, age between 18 to 35 years, admitted under Obstetrics \& Gynaecology department, Gauhati Medical College \& Hospital, Guwahati, during the period August 2015 to July 2016.

b) Case group $1=30$ newly diagnosed cases of Mild Pre-Eclampsia women of $>20$ weeks of gestation, age between 18 to 35 years.

c) Case group $2=30$ newly diagnosed cases of Severe Pre-Eclampsia women of $>20$ weeks of gestation, age between 18 to 35 years.

This is a case control study where in a thorough history was taken and detailed physical examination and relevant laboratory investigations were done for all the subjects as per the Proforma after taking their informed consent.

\section{Exclusion criteria}

$>$ Pregnant women with essential hypertension or hypertension $<20$ weeks gestation.

$>$ Pre-existing diabetes mellitus, renal disease, liver disorder, heart disease, epilepsy \& with urinary tract infection.

\section{Sample collection}

Taking all aseptic and antiseptic precautions, $5 \mathrm{ml}$ of blood was drawn from the median cubital vein. Fasting samples were used for all the investigations.

\section{Sample analysis}

1. Estimation of Fasting Plasma Glucose, Serum Urea, Serum Creatinine, Serum Alanine Transaminase (ALT), Serum Aspartate Transaminase (AST), ALKP, Serum Total Protein, Serum Albumin profile - MERCK microlab 300 Semiautoanalyser.

2. Estimation of serum Uric Acid was done by using MERCK microlab 300 Semiautoanalyser. Serum Uric Acid was measured quantitatively by using Uricase/ POD method Uric Acid in vitro diagnostic kit.

3. Estimation of Serum Lactate Dehydrogenase was done by using MERCK microlab 300 
Semiautoanalyser. Serum Lactate

Dehydrogenase was measured quantitatively by using SIEMENS AUTOPAK ${ }^{\circledR} \mathrm{LDH}$ in vitro diagnostic kit.

4. Anthropometric parameters like Height (m), Weight (kg), BMI, Waist, Hip and Waist- Hip ratio was measured by standard method.

After the biochemical estimations, the results obtained were statistically analyzed and compared between the three groups of the study. Baseline characteristics of the study participants are expressed in mean $\pm \mathrm{SD}$. One way Analysis of variance (ANOVA) test were used to analyze differences in baseline characteristics between the studied groups.

Correlations were observed by using Pearson's correlation coefficient. The results were considered significant when the probability ( $p$ value) was less than 0.05 . Statistical analysis was done using Graph Pad In Stat version 3.00. All the statistical graphs were prepared using Microsoft Excel 2007.

\section{Results}

Table 1: Mean of Anthropometric measurements in study groups

\begin{tabular}{|l|c|c|c|c|}
\hline Measurements & $\begin{array}{c}\text { Controls } \\
(\mathbf{m e a n} \pm \text { SD) }\end{array}$ & $\begin{array}{c}\text { Cases (Mild Pre-Eclampsia) } \\
(\mathbf{m e a} \pm \mathbf{S D})\end{array}$ & $\begin{array}{c}\text { Cases (Severe Pre-Eclampsia) } \\
(\mathbf{m e a n} \pm \text { SD) }\end{array}$ & p value \\
\hline Weight $(\mathbf{K g})$ & $51.87 \pm 5.88$ & $54.73 \pm 4.41$ & $60.53 \pm 3.43$ & $<0.0001$ \\
\hline $\begin{array}{l}\text { BMI } \\
\left(\mathbf{K g} / \mathbf{m}^{2}\right)\end{array}$ & $20.69 \pm 3.36$ & $22 \pm 3.48$ & $24.39 \pm 3.89$ & $<0.0001$ \\
\hline
\end{tabular}

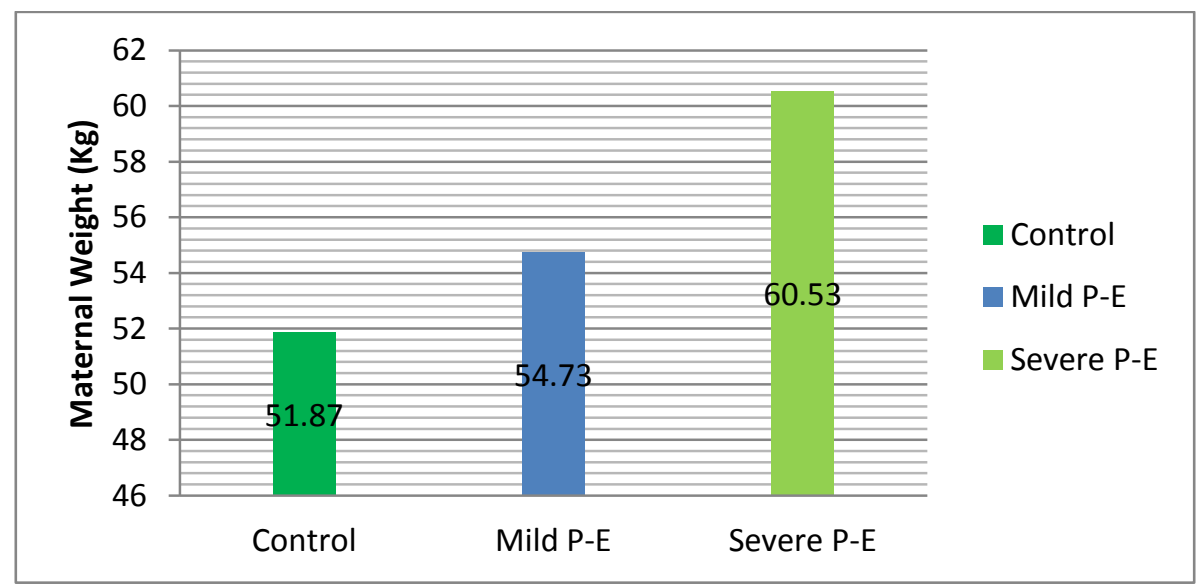

Figure 1: Comparison of mean Weight $(\mathrm{Kg})$ in controls and cases

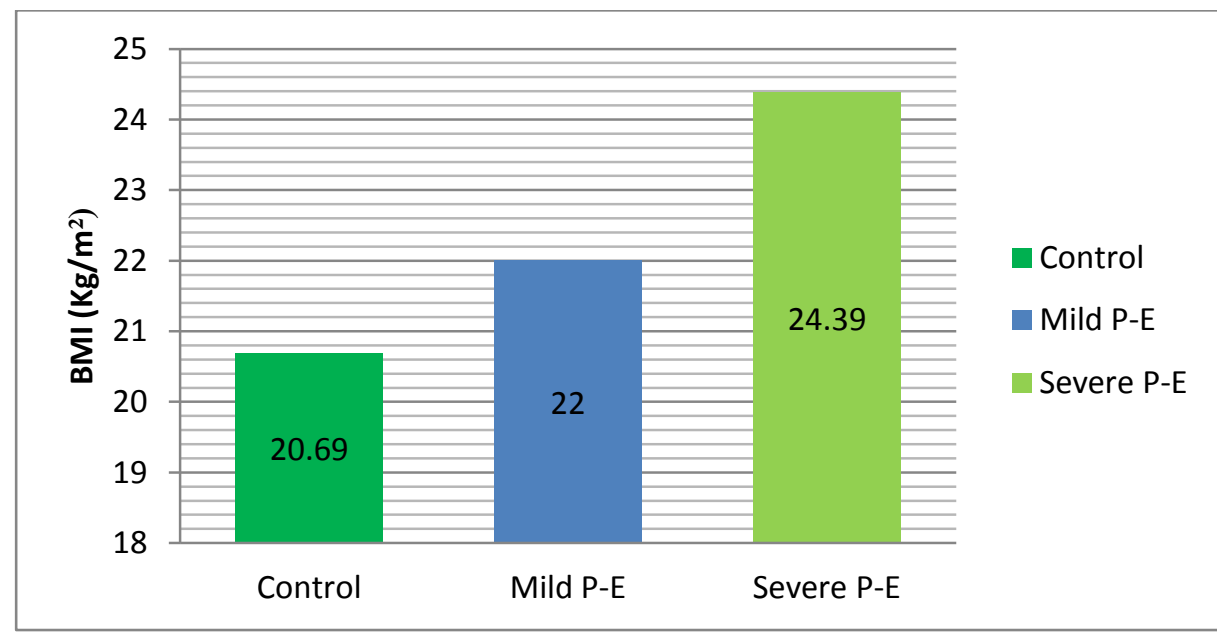

Figure 2: Comparison of mean BMI $\left(\mathrm{Kg} / \mathrm{m}^{2}\right)$ in controls and cases

There was extremely significant $(\mathrm{p}<0.0001)$ difference in Weight, BMI between the control and case groups (Table 1). 
Table 2: Shows comparison between the other important Parameters of the study groups. Values expressed as mean \pm SD. Ordinary One Way Analysis of Variance (ANOVA) test with Standard Parametric Method were used for comparison of means between the study groups.

\begin{tabular}{|l|c|c|c|c|}
\hline Parameters & $\begin{array}{c}\text { Controls } \\
(\mathbf{m e a n} \pm \text { SD })\end{array}$ & $\begin{array}{c}\text { Cases (Mild Pre-Eclampsia) } \\
(\mathbf{m e a n} \pm \text { SD) }\end{array}$ & $\begin{array}{c}\text { Cases (Severe Pre-Eclampsia) } \\
(\text { mean } \pm \text { SD })\end{array}$ & p value \\
\hline $\begin{array}{l}\text { Systolic BP } \\
(\mathbf{m m} \text { Hg) }\end{array}$ & $103.98 \pm 11.10$ & $149.1 \pm 7.13$ & $172.9 \pm 10.28$ & $<0.0001$ \\
\hline $\begin{array}{l}\text { Diastolic BP } \\
(\mathbf{m m} \text { Hg) }\end{array}$ & $71.6 \pm 11.80$ & $104.2 \pm 11.28$ & $118 \pm 7.81$ & $<0.0001$ \\
\hline $\begin{array}{l}\text { Platelets } \\
(\times \mathbf{1 0} / \mathbf{L})\end{array}$ & $164.35 \pm 8.41$ & $116.9 \pm 5.90$ & $102.97 \pm 8.66$ & $<0.0001$ \\
\hline
\end{tabular}

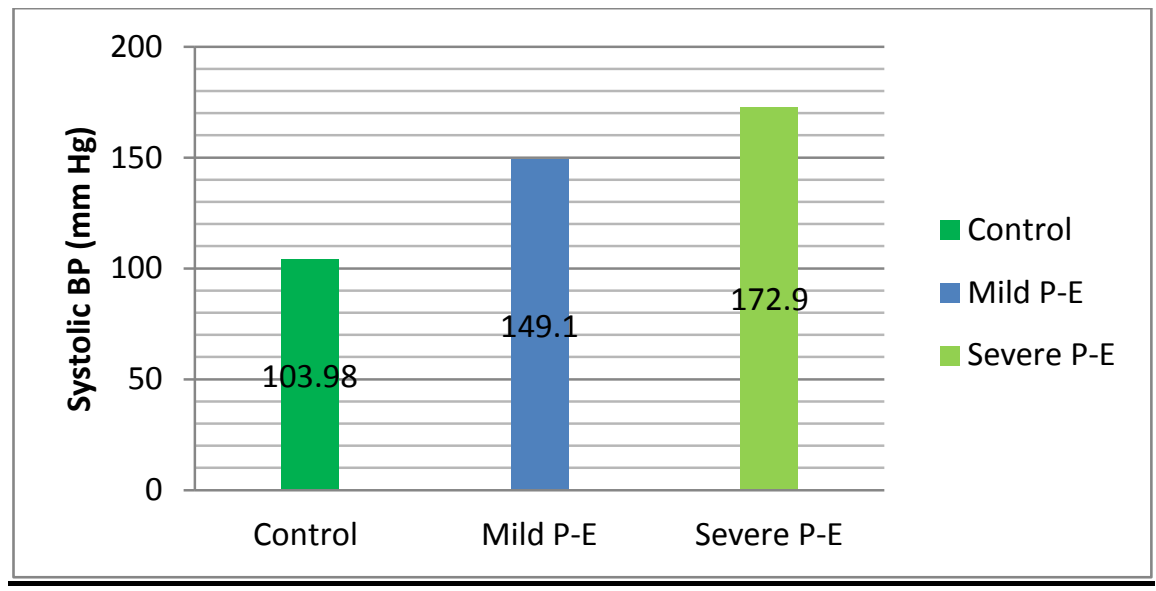

Figure 3: Comparison of mean Systolic BP $(\mathrm{mm} \mathrm{Hg})$ in controls and cases

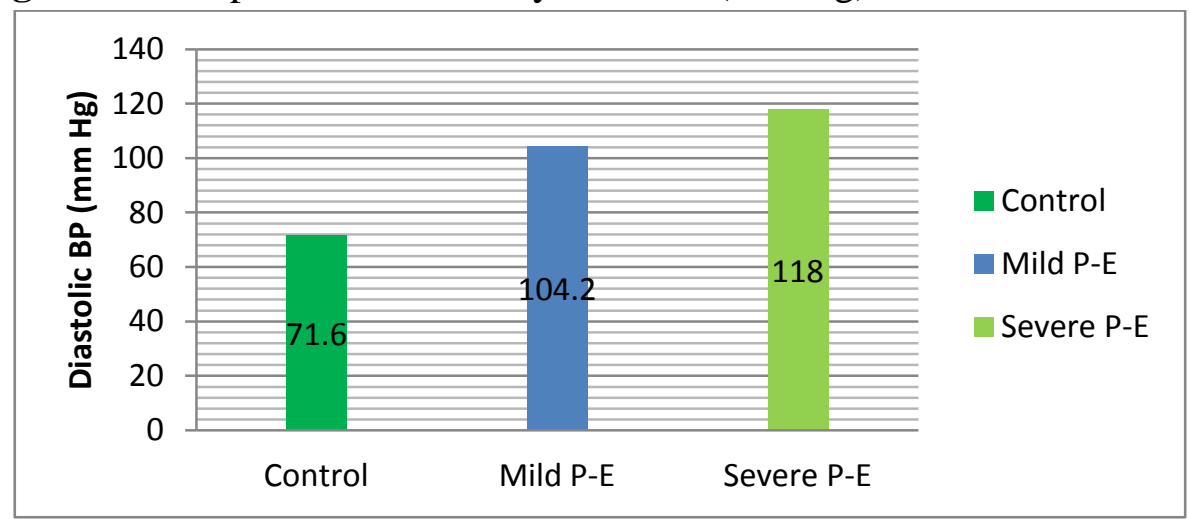

Figure 4: Comparison of mean Diastolic BP ( $\mathrm{mm} \mathrm{Hg})$ in controls and cases

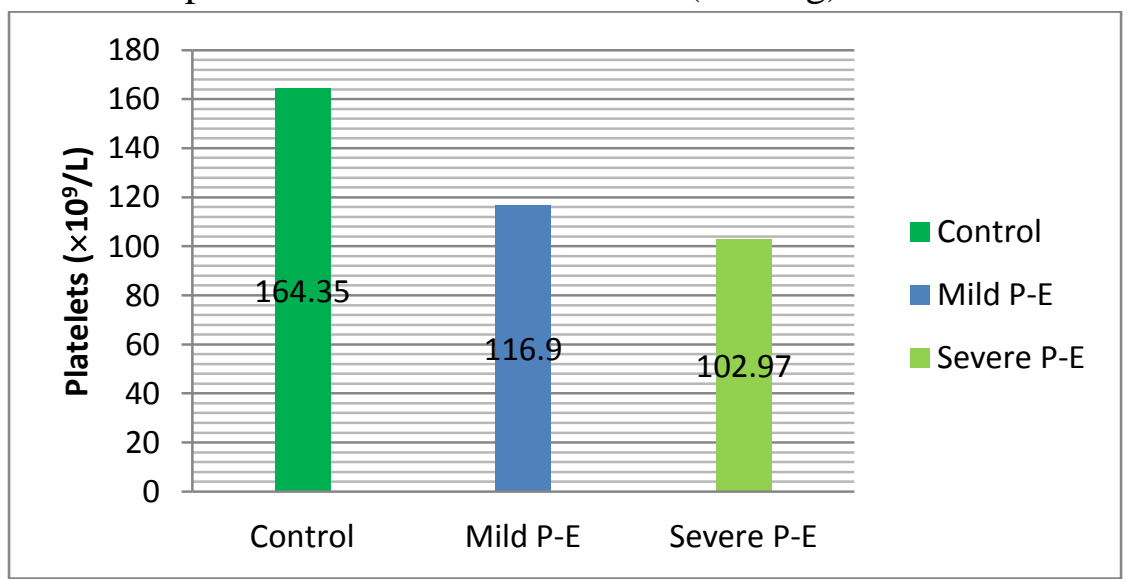

Figure 5: Comparison of mean Platelets $\left(\times 10^{9} / \mathrm{L}\right)$ in controls and cases There was extremely significant difference $(\mathrm{p}<0.0001)$ in Systolic, Diastolic BP, mean Platelets between the control and case groups (Table 2). 
Table 3: Shows comparison between the biochemical parameters of the study groups. Values expressed as mean \pm SD. Ordinary One Way Analysis of Variance (ANOVA) test with Standard Parametric Method were used for comparison of means between the study groups

\begin{tabular}{|l|c|c|c|c|}
\hline Parameters & $\begin{array}{c}\text { Controls } \\
(\text { mean } \pm \text { SD })\end{array}$ & $\begin{array}{c}\text { Cases (Mild Pre- } \\
\text { Eclampsia) } \\
(\mathbf{m e a n} \pm \text { SD) }\end{array}$ & $\begin{array}{c}\text { Cases } \\
\text { (Severe Pre-Eclampsia) } \\
(\mathbf{m e a n} \pm \text { SD) }\end{array}$ & p value \\
\hline Creatinine (mg/dl) & $0.55 \pm 0.16$ & $1.47 \pm 0.47$ & $2.47 \pm 0.74$ & $<0.0001$ \\
\hline AST (U/ml) & $35.95 \pm 7.96$ & $65.07 \pm 15.09$ & $160 \pm 40.35$ & $<0.0001$ \\
\hline ALT (U/ml) & $26.85 \pm 5.79$ & $74.93 \pm 26.92$ & $196.73 \pm 92.86$ & $<0.0001$ \\
\hline ALKP (U/L) & $87.52 \pm 21.92$ & $141.47 \pm 13.16$ & $219.73 \pm 65.53$ & $<0.0001$ \\
\hline Total Protein $(\mathbf{g m} / \mathbf{d l})$ & $6.93 \pm 0.66$ & $6.53 \pm 0.71$ & $6.03 \pm 0.47$ & $<0.0001$ \\
\hline Serum Albumin $\mathbf{( g m / d l )}$ & $5.09 \pm 0.82$ & $4.47 \pm 0.90$ & $3.73 \pm 0.62$ & $<0.0001$ \\
\hline LDH (U/L) & $381.05 \pm 123.68$ & $597.57 \pm 52.55$ & $714.3 \pm 80.04$ & $<0.0001$ \\
\hline $\begin{array}{l}\text { Uric Acid } \\
(\mathbf{m g} / \mathbf{d l})\end{array}$ & $4.49 \pm 1.33$ & $7.15 \pm 1.16$ & $8.24 \pm 2.09$ & $<0.0001$ \\
\hline
\end{tabular}

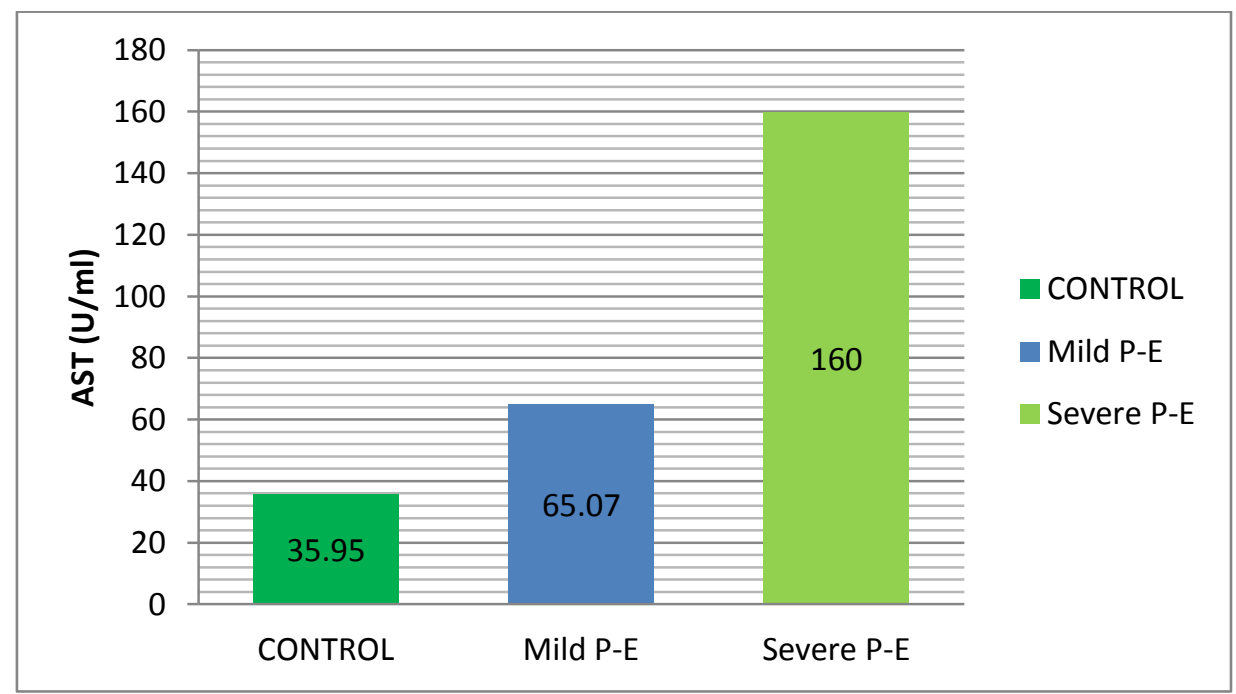

Figure 6: Comparison of mean AST (U/ml) in controls and cases

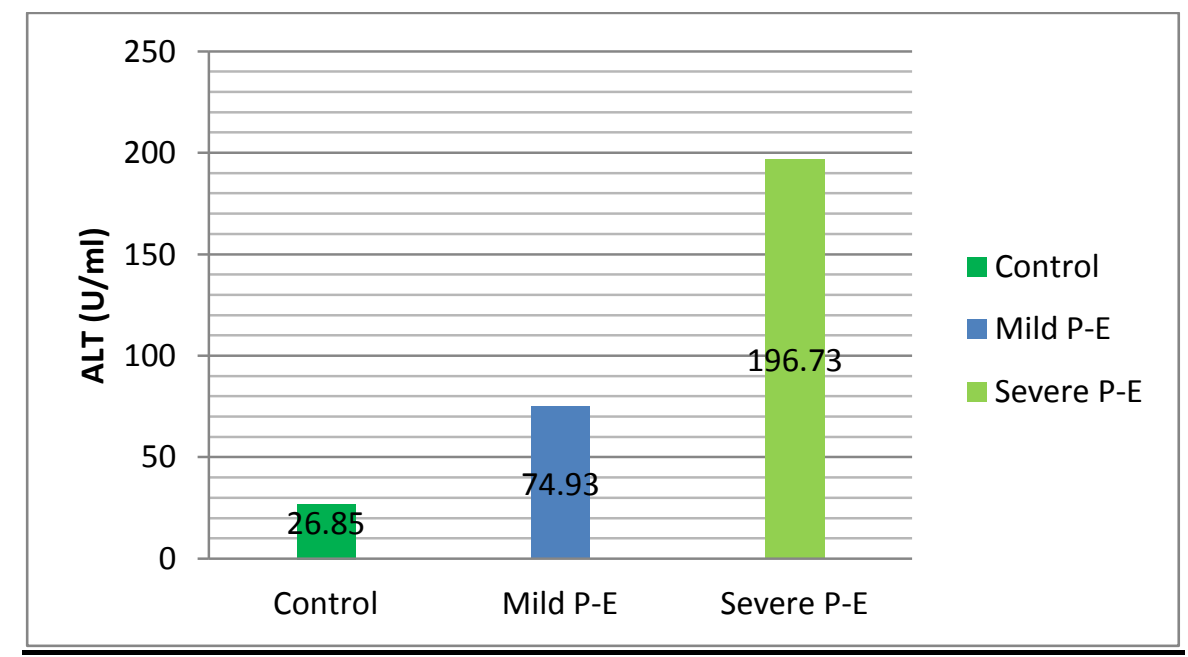

Figure 7: Comparison of mean ALT (U/ml) in controls and cases 


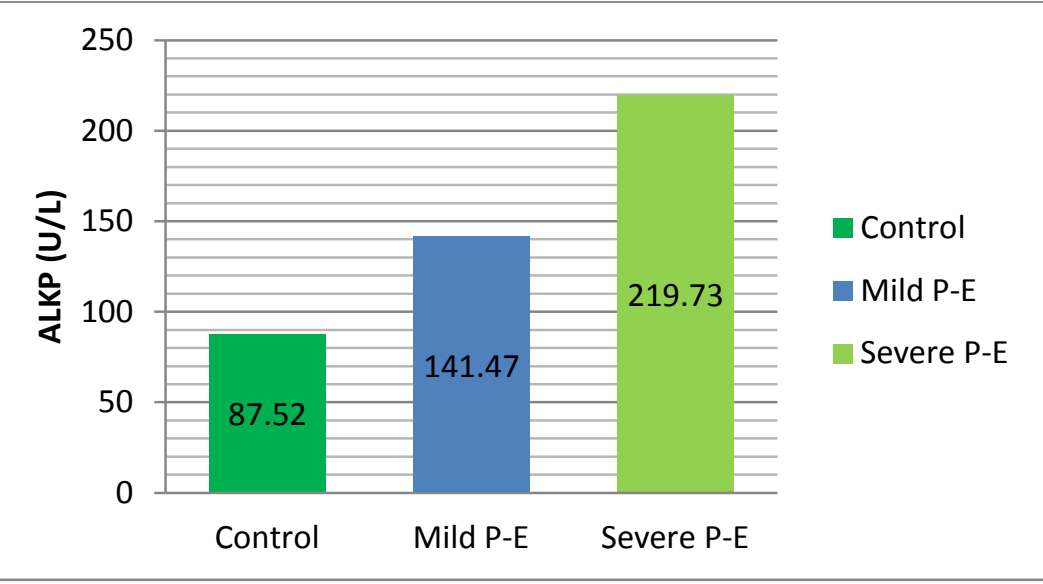

Figure 8: Comparison of mean ALKP (U/L) in controls and cases

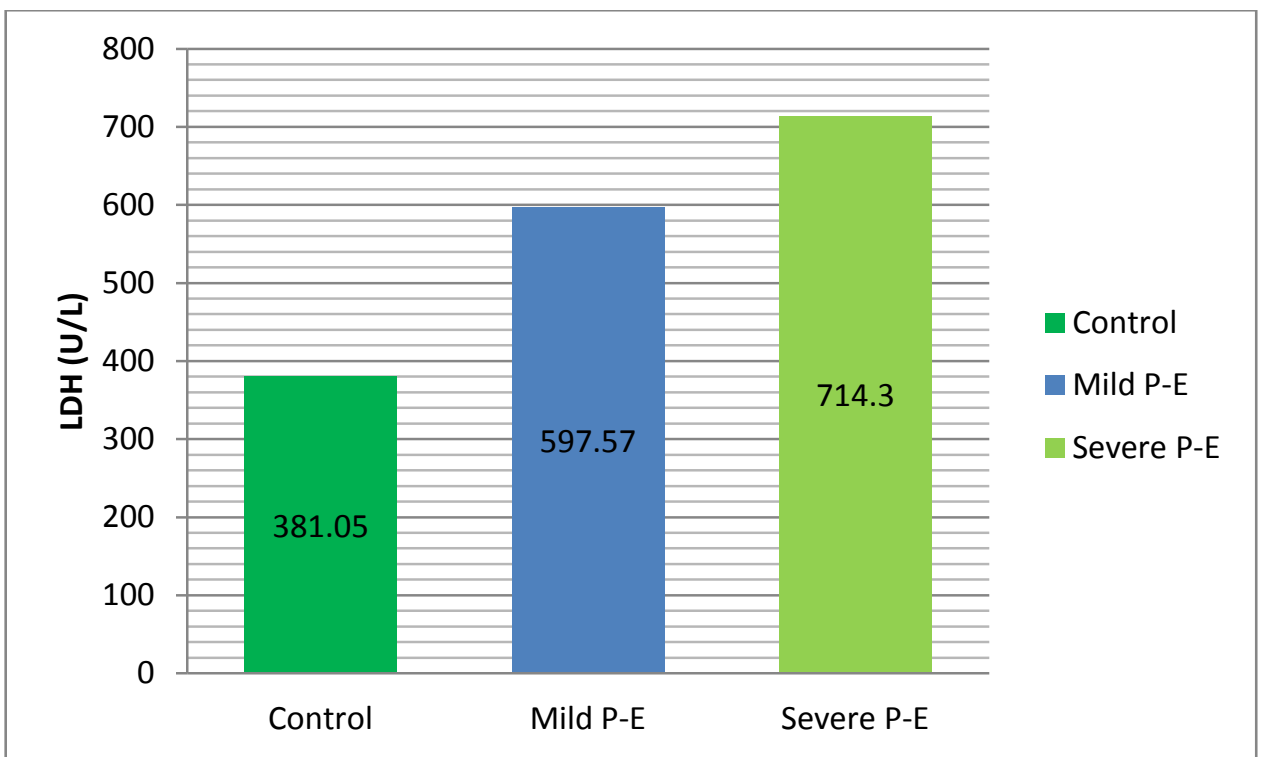

Figure 9: Comparison of mean LDH (U/L) in controls and cases

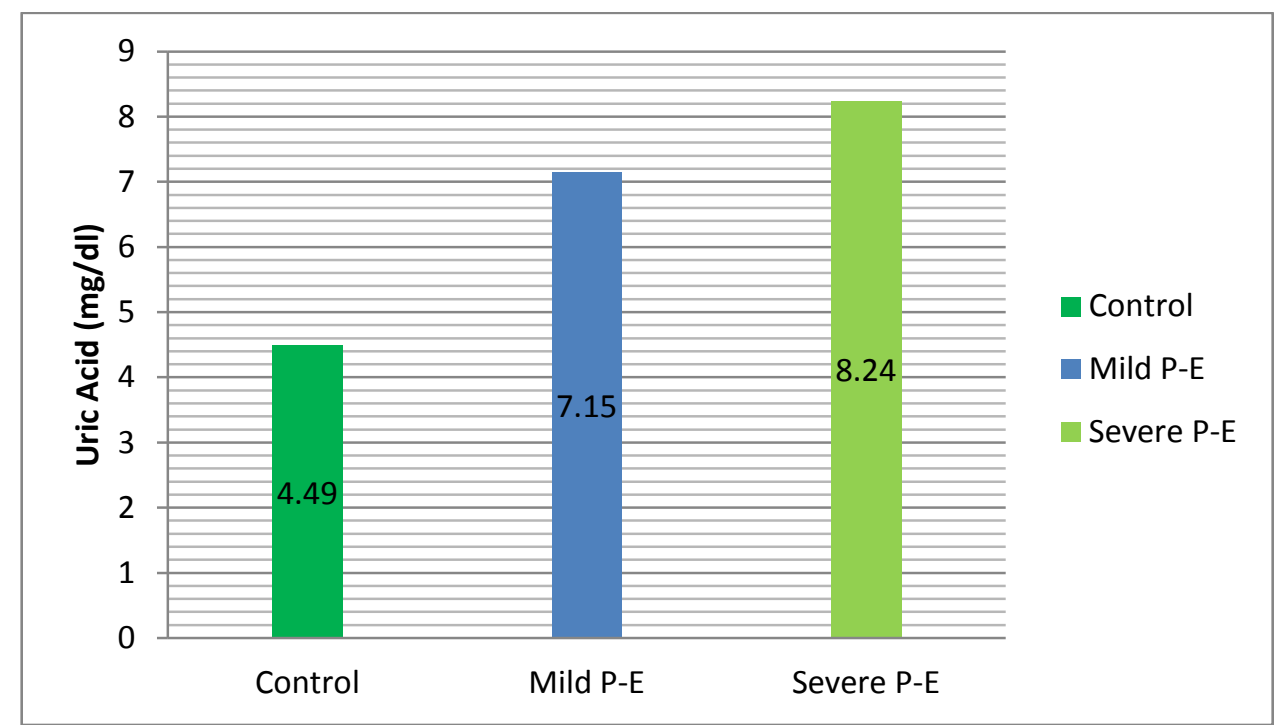

Figure 10: Comparison of mean Uric Acid (mg/dl) in controls and cases

There was extremely significant difference $(\mathrm{p}<0.0001)$ between Serum Creatinine, AST, ALT, ALKP, Total Protein, Albumin, LDH, Uric Acid the control and case groups (Table 3). 
Pearson's correlation was derived between Serum LDH with other parameters in Pre-Eclampsia (Table 4)

Table 4: Correlation of LDH with other Parameters Studied in Pre-Eclampsia

\begin{tabular}{|l|c|c|c|c|c|}
\hline \multicolumn{2}{|c|}{ MILD PRE-ECLAMPSIA } & \multicolumn{2}{c|}{ SEVERE PRE-ECLAMPSIA } \\
\hline \multirow{2}{*}{ PARAMETER } & \multicolumn{2}{|c|}{ PDH } & & \multicolumn{2}{c|}{ LDH } \\
\cline { 2 - 5 } & r value & p value & & r value & p value \\
\hline 1.Systolic BP (mmHg) & 0.622 & 0.0002 & 1. Systolic BP $(\mathrm{mm} \mathrm{Hg})$ & 0.767 & $<0.0001$ \\
\hline 2.Diastolic BP (mmHg) & 0.681 & $<0.0001$ & 2.Diastolic BP $(\mathrm{mm} \mathrm{Hg})$ & 0.574 & 0.0009 \\
\hline 3. ALKP (U/L) & 0.398 & 0.029 & 3. ALKP (U/L) & 0.499 & 0.005 \\
\hline 4. Uric Acid (mg/dl) & 0.744 & $<0.0001$ & 4. Uric Acid (mg/dl) & 0.392 & 0.032 \\
\hline
\end{tabular}

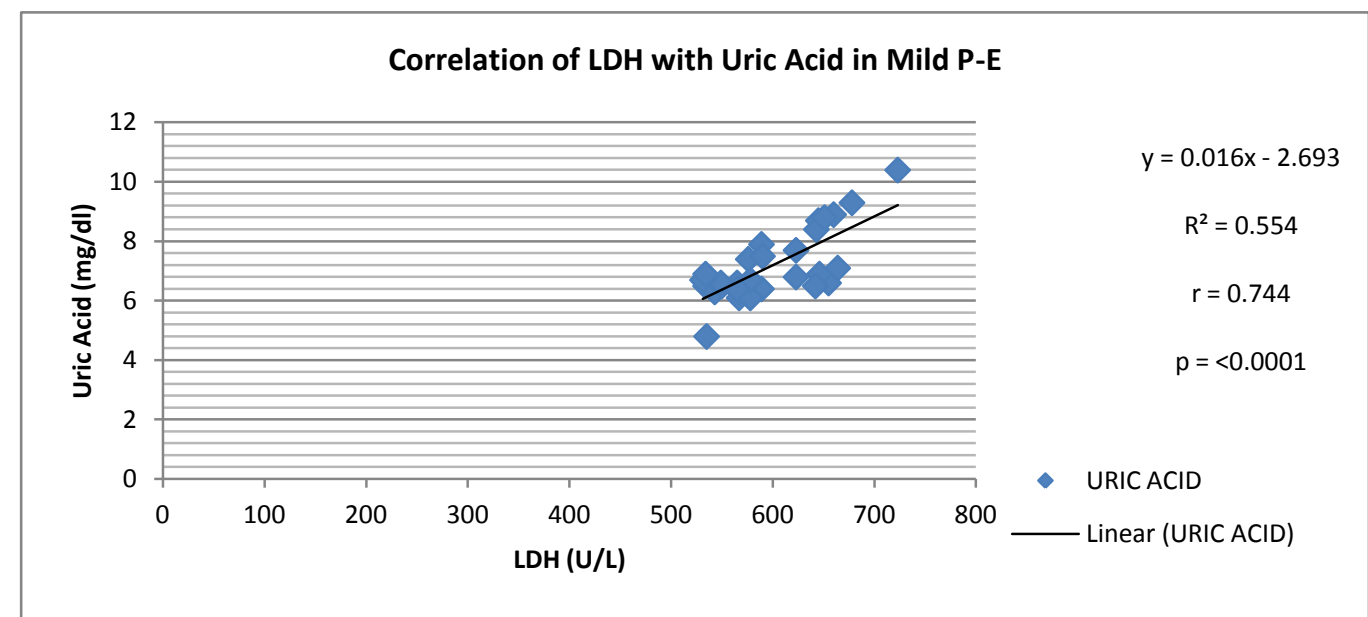

Graph 1: Correlation of LDH with Uric Acid in Mild P-E.

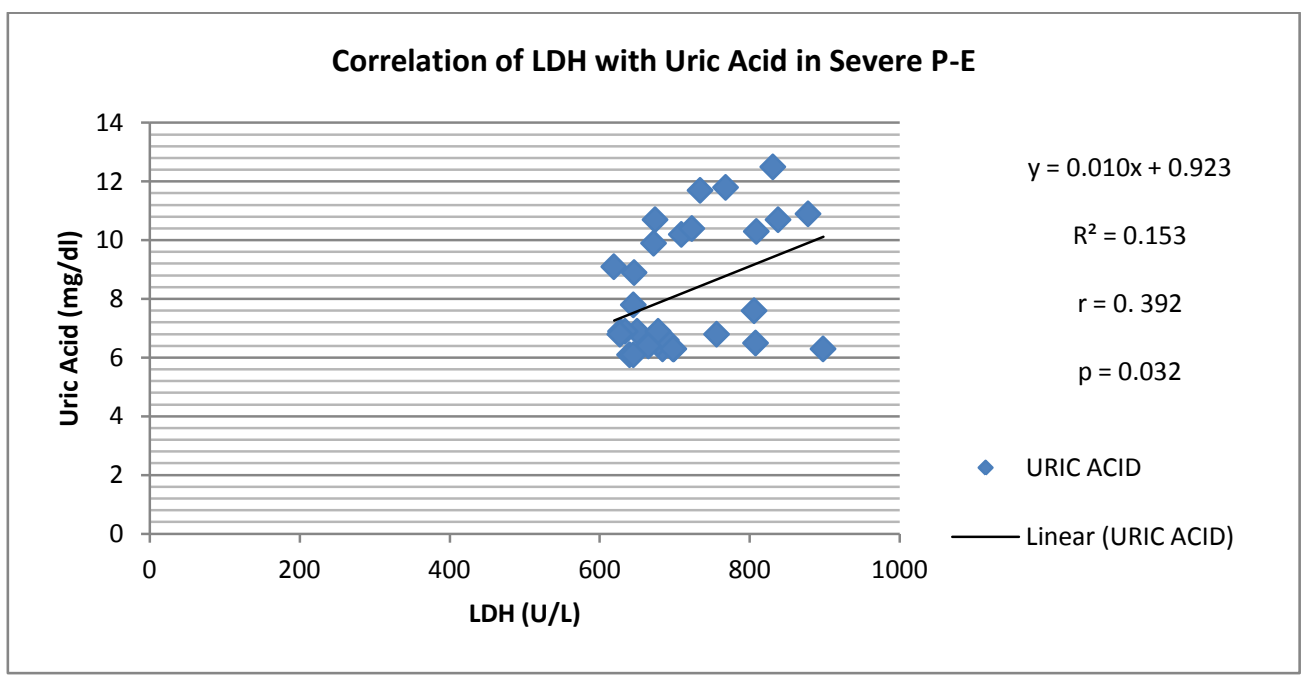

Graph 2: Correlation of LDH with Uric Acid in Severe P-E.

Pearson's correlation was derived between Serum Uric Acid with other parameters in Pre-Eclampsia: (Table 5)

Table 5: Correlation of Uric Acid with other Parameters studied in Pre-Eclampsia

\begin{tabular}{|c|c|c|c|c|c|}
\hline \multicolumn{3}{|c|}{ MILD PRE-ECLAMPSIA } & \multicolumn{3}{|c|}{ SEVERE PRE-ECLAMPSIA } \\
\hline \multirow[t]{2}{*}{ PARAMETER } & \multicolumn{2}{|c|}{ URIC ACID } & \multirow[t]{2}{*}{ PARAMETER } & \multicolumn{2}{|c|}{ URIC ACID } \\
\hline & r value & p value & & r value & p value \\
\hline $\begin{array}{l}\text { 1. Systolic BP } \\
\text { (mm Hg) }\end{array}$ & 0.622 & 0.0002 & $\begin{array}{l}\text { 1. Systolic BP } \\
\text { (mm Hg) }\end{array}$ & 0.352 & 0.056 \\
\hline $\begin{array}{l}\text { 2. Diastolic BP } \\
\text { (mm Hg) }\end{array}$ & 0.692 & $<0.0001$ & $\begin{array}{l}\text { 2. Diastolic BP } \\
(\mathrm{mm} \mathrm{Hg})\end{array}$ & 0.740 & $<0.0001$ \\
\hline 3. ALKP (U/L) & 0.319 & 0.085 & 3. ALKP (U/L) & 0.696 & $<0.0001$ \\
\hline 4. LDH (U/L) & 0.744 & $<0.0001$ & 4. LDH (U/L) & 0.391 & 0.032 \\
\hline
\end{tabular}




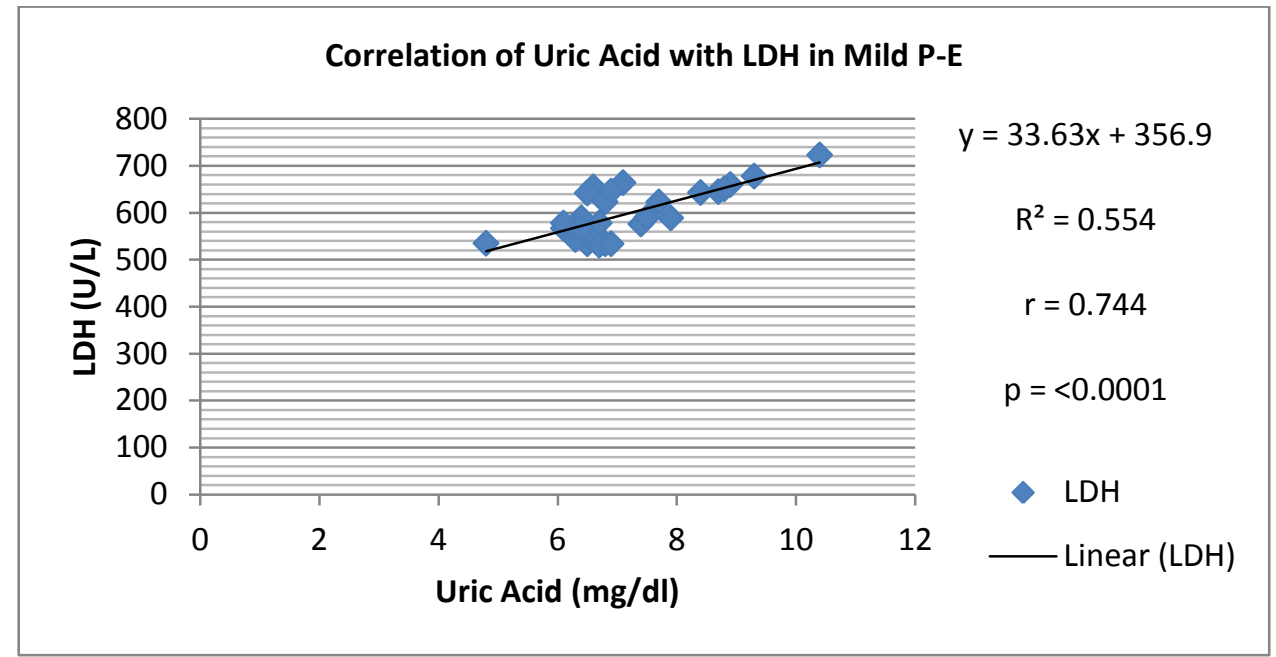

Graph 3: Correlation o Uric Acid with LDH in Mild P-E.

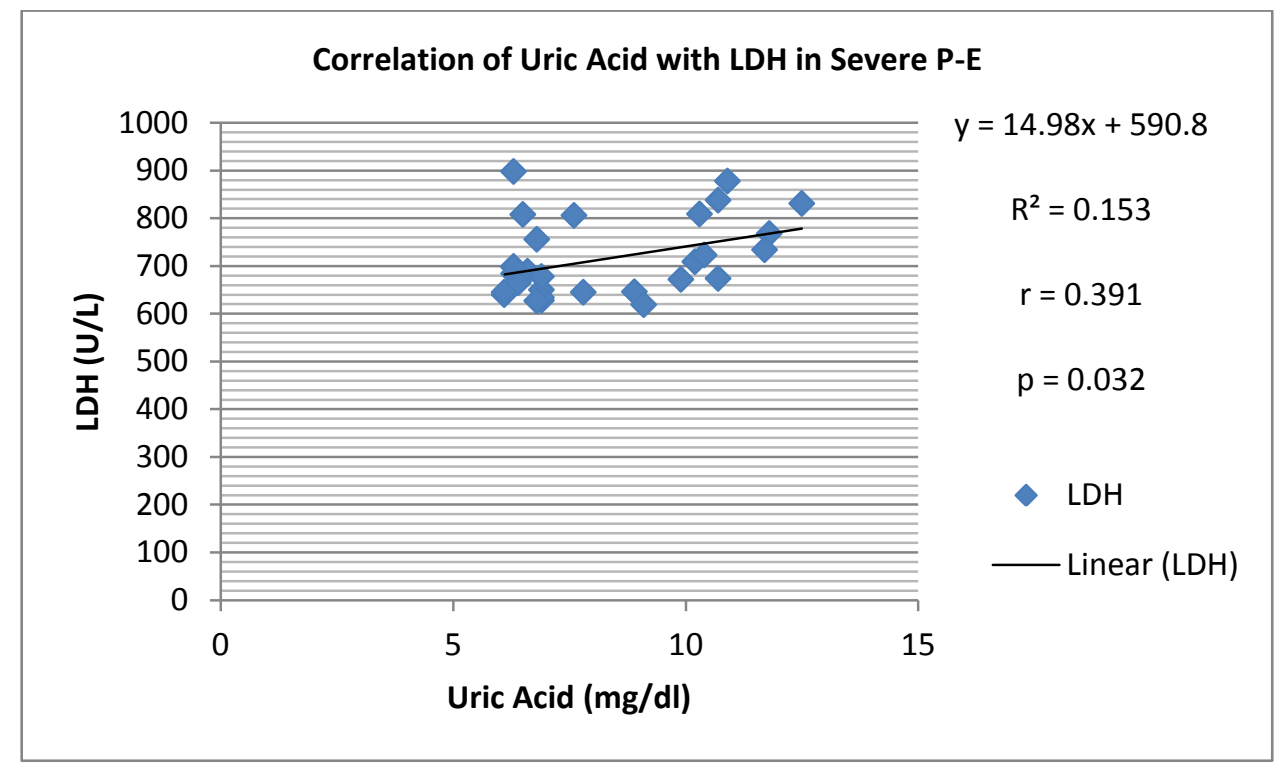

Graph 4: Correlation o Uric Acid with LDH in Severe P-E.

\section{Discussion}

Pre-Eclampsia, as one of the most common and important hypertensive disorders of pregnancy, is a major health problem worldwide and a threat to mothers and infants' well-being. ${ }^{24}$

One of the most common causes is Gestational Hypertension and its fatal complications leading to pulmonary edema, acute renal failure, hepatic rupture, abruptio placentae, ophthalmological problems, disseminated intravascular coagulation and hemolysis, elevated liver enzymes and low platelet count (HELLP syndrome). ${ }^{25}$

In our study, we found the mean Serum LDH of the Mild Pre-Eclampsia patients was 597.57 U/L and the mean Serum LDH of the Severe PreEclampsia patients was $714.3 \mathrm{U} / \mathrm{L}$ and the difference was extremely significant $\mathrm{p}<0.0001$ (Table 3). The finding of the present study was in corroboration with the studies by S.M Munde et al (2014), ${ }^{26}$ H.S Qublan et al (2005) ${ }^{13}$ and Sonagra A.D et al (2012). ${ }^{15}$ They found the mean LDH of Pre-Eclampsia patients as $535.22 \pm 44.82 \mathrm{U} / \mathrm{L}$ (Mild P-E) ${ }^{26} \& 819.88 \pm 90.7$ U/L (Severe P-E) ${ }^{26}$, $348 \pm 76$ U/L (Mild P-E) ${ }^{13} \&$ 774.9 $\pm 69.6 \quad \mathrm{U} / \mathrm{L}$ (Severe P-E) ${ }^{13}$ and $356.46 \pm 158.09 \quad \mathrm{U} / \mathrm{L}^{15}$ respectively and there was extremely significant $(\mathrm{p}<0.0001)$ difference in mean LDH between the control and case groups. H.S Qublan et al (2005) $)^{13}$ showed highly significant increase in LDH activity in Severe Pre-Eclampsia women than normal pregnant women. 
In the present study, the mean Serum Uric Acid of the Mild Pre-Eclampsia patients was 7.15 $\mathrm{mg} / \mathrm{dland}$ the mean Serum Uric Acid of the Severe Pre-Eclampsia patients was $8.24 \mathrm{mg} / \mathrm{dl}$ and the difference was extremely significant $\mathrm{p}<0.0001$ (Table 3). The finding of the present study was in corroboration with the studies by Sonagra A.D et al (2012), ${ }^{15}$ Vyakaranam S et al (2015) ${ }^{27}$ and Sirajwala B.H et al (2013). ${ }^{28}$ They found the mean Uric Acid of Pre-Eclampsia patients as $5.83 \pm 0.71$ $\mathrm{mg} / \mathrm{dl},{ }^{15} 6.26 \pm 1.19 \mathrm{mg} / \mathrm{dl}^{27}, 7.6 \pm 0.55 \mathrm{mg} / \mathrm{dl}$ (Mild P-E) ${ }^{28} \& \quad 8.33 \pm 0.46 \mathrm{mg} / \mathrm{dl} \quad$ (Severe P-E) ${ }^{28}$ respectively andthere was extremely significant $(p<0.0001)$ difference in mean Uric Acid between the control and case groups.

Mansi Gandhi et al (2015) ${ }^{29}$ found that the Hypertensive disorders of pregnancy are commonly associated with a decrease in renal function due to damage done by hypertension and wide spread endothelial dysfunction. The net effects have reduced renal blood flow, reduced GFR, impaired tubular reabsorption \& secretory function. ${ }^{30,31}$

Bainbridge et al (2009) ${ }^{32}$ suggested that hyperuricemia in Pre-Eclampsia is multifactorial. In Pre-Eclampsia, elevated levels of Uric Acid are not only attributed to decreased renal excretion but also to increased oxidative stress resulting from placental ischemia and xanthine oxidase activity. $^{33}$

Maternal hyper uricemia is found to be a strong predictor of maternal disease progression and fetal outcome. Thus, it can be used as useful and inexpensive marker for predicting disease severity, renal function status and fetal growth retardation in women presenting with Hypertensive disorder of pregnancy. ${ }^{34}$

\section{Conclusion}

Pre-Eclampsia is a Pregnancy-specific disease and in its severe form, serious multi system complications may occur. Serum LDH is the earliest marker seen in blood during hypoxia and oxidative stress. Increased levels of LDH indicative the cellular damage and dysfunction can be used as a biochemical marker because it reflects the severity of the disease and the occurrence of complication of Pre-Eclampsia, these are preventable if identified at an earlier stage and adequately managed at higher centre. The test is easily available.

Detection of high risk patients with increased levels of LDH mandate close monitoring and correct management to decreased both maternal and fetal morbidity and mortality.

Uric Acid is a marker of oxidative stress, tissue injury and renal dysfunction; it is possible that uric acid merely identifies a more severe form of Pre-Eclampsia. The Serum Uric Acid measurement was one of the best markers of the diagnosis as well as severity of Pre-Eclampsia and will be a useful index for the management of the same.

So, Serum LDH Levels and Uric Acid can be used as tool in making decision, regarding the management strategies to improve the maternal and fetal outcome. However, further studies on a larger population needs to be undertaken to validate its sensitivity and specificity.

\section{Bibliography}

1. Cunningham F, Lenevo K, Bloom S, Hauth J, Gilstrap L, Wenstrom K. ln Maternal physiology. Williams Obstetrics 23rd edn. New York 2011; Mc Graw Hill: 107-131.

2. Cengiz C, Kimya Y Maternal Fizyoloji. Temel Kadın Hastalıklarıve Dogum Bilgisi (Eds Kisnisçi et al) Günes; Ankara.1997: 242243.

3. Chapman JF, Tsongalis GJ. Pregnancy and fetal development. Clinical Chemistry. 1996; Kaplan LA, Pesce AJ eds Missouri Mosby: 799-810.

4. Herrera E, Gomez DC, Lasuncion MA. Lipid metabolism in pregnancy. Biol Neonate.1987; 52(2): 70-77.

5. Park K. Textbook of preventive and social medicine 21st edn. Preventative medicine in obstetrics, pediatrics \& geriatrics. 2011; M/s Banarasidas Bhanot publishers: 514-517. 
6. Cunningham F, Lenevo K, Bloom S, Hauth J, Gilstrap L, Wenstrom K. In Maternal physiology. Williams Obstetrics 23rd edn. New York 2011; Mc Graw Hill: 707.

7. Packer CS. Biochemical markers and physiological parameters as indices for identifying patients at risk of developing preeclampsia. J Hypertens. 2005; 23(1): 45-46.

8. Duley L. Pre-eclampsia and the Hypertensive disorders of pregnancy. Br Med J. 2003; 67: 161.

9. WHO. Make every mother and child count. The World Health Report. 2005; Geneva Switzerland: World Health Organization.

10. Bansal S. Hypertension in pregnancy. In: Desai P, Malhotra N, Shah D eds. Principles \& practice of Obstetrics \& Gynaecology for post-graduates. 3rd ed. Jaypee Brothers, New Delhi, 2008; 100-107.

11. International Institute for Population Sciences \& Macro International: National Family Health Survey (NFHS-3), 2005-06: India: Vol. I. Mumbai, IIPS; 2007.

12. Agrawal, Walia. J Womens Health Issues Care. 2014; 3: 6 http://dx.doi.org/10.4172/23259795.100016

13. H.S Qublan, Ammarin V, Bataineh O, Al Shraideh Z, Tahat Y, Awamleh I et al. Lactic dehydrogenase as a biochemical marker of adverse pregnancy outcome in severe preeclampsia. Med Sci Monit. 2005; 11(8): CR393-397.

14. Jaiswar S.P, Gupta Amrit, Sachan Rekha, Natu S.N, Shaili Mohan. Lactic Dehydrogenase: A biochemical AMrker for preeclampsia-eclampsia. JOGI. Nov-Dec 2011, 61(6): 645-648.

15. Sonagra A.D, Dattatreya. K, Jayaprakash Murthy D.S. Serum LDH,ALP and Uric Acid in Hypertensive Disorders of Pregnancy. IJPBS. July-Sept 2012; 2(3): 201-209.

16. Tsoi S, Zheng J, Xu F, Kay H. Differential expression of lactate dehydrogenase isozymes (LDH) in human placenta with high expression of $\mathrm{LDH}-\mathrm{A}(4)$ isozyme in the endothelial cells of pre-eclampsia villi. Placenta.2001; 22(4): 317-322.

17. Sharma J, Sharma A, Bahadur A, Vimala N, Satyam A,et al. Oxidative stress markers and antioxidant levels in normal pregnancy and pre-eclampsia. International Journal of Gynecology and Obstetrics. 2006; 94: 23-27.

18. Krefetz RG. Enzymes. Clinical Chemistry, 4th ed. Lippincott Williams and Wikins. Philadelphia 2000; 196-198.

19. Vasudevan D, Sreekumari S, Vaidyanathan K (eds). Kidney function tests. Textbook of biochemistry, 6th edn. Jaypee Brothers, New Delhi. 2011; 314-328.

20. Davison J, Homuth V, Jeyabalan A, Conrad K, Karumanchi A,et al. New aspects in the pathophysiology of preeclampsia. J Am Soc Nephrol. 2004; 15: 2440-2448.

21. Cunningham F, Lenevo K, Bloom S, Hauth J, Gilstrap L, Wenstrom K. ln Maternal physiology. Williams Obstetrics 23rd edn. New York 2011; Mc Graw Hill: 712-713.

22. Sharma J, Sharma A, Bahadur A, Vimala N, Satyam A,et al. Oxidative stress markers and antioxidant levels in normal pregnancy and pre-eclampsia. International Journal of Gynecology and Obstetrics. 2006; 94: 23-27.

23. Gary Cunningham F, Kenneth J Leveno, steven 1 Bloom, John C Hauth, Dwight J Rouse, Catherine Y Sponge editors. Wlliams Obstetrics. 23 ${ }^{\text {rd }}$ Edition. The McGraw Hill Company; 2010: 1261.

24. Yucesoy G, Ozkan S, Bodur H, Tan T, Caliskan E, Vural B, et al. Maternaland perinatal outcome in pregnancies complicated with hypertensive disorder of pregnancy: a seven year experience of atertiarycare center. Arch Gynecol Obstet. 2005; 273(1):43-9.

25. Norwitz ER, Hsu CD, Repke JT. Acute complications of preeclampsia. Clin Obstet Gynecol.2002; 45: 308-29.

26. S.M Munde, Hazari N.R, Thorat A.P, Gaikwad S.B, Hatolkar V.S. Gamma Glutamyl Transferase and Lactate Dehydrogenase as biochemical markers of 
severity of Pre-Eclampsia. International Journal of Medical, Health, Biomedical, Bioengineering and Pharmaceutical Engineering. 2014; 8(1): 50-53.

27. Vyakaranam S, Bhongir Verma A, Patlolla D. Study of serum Uric Acid and creatinine in hypertensive disorders of pregnancy. International Journal of Medical Science and Public Health. 2015; 4(10): 1424-1428.

28. Sirjwala B.H, Sharma D, Agravatt A.M. Astudy of seru, total calcium and Uric Acid in Pre-Eclampsia. Indian Journal of Basic and Applied Medical Research. 2013; 1(3): 50-56.

29. Mansi Gandhi. International Journal of Biomedical Research. 2015; 6(01): 25-28.

30. Datta D. Hypertensive disorders in pregnancy. In: Konor H. ed. DC Datta's Textbook of obstetrics. 7th ed. New Central book agency (P) Ltd. Kolkata 2011; 219-240.

31. Pregnancy hypertension. In : Cunningham F, Lenevo K, Bloom S, Hauth J, Gilstrap L, Wenstrom K, edts. Williams Obstetrics, 23rd edn. Mc Graw Hill, New York 2011, pp706728.

32. Bainbridge SA, Von Versen-Hoynck F RJ. Uric acid inhibits placental system an amino acid uptake. Placenta. 2009;30: 195-200.

33. Livingston JR, Payne B, Brown M, Roberts JM, Côté A, Magee LA, et al. Uric acid as a predictor of adverse maternal and perinatal outcomes in women hospitalized with preeclampsia. J Obstet Gynecol 2014;7: 8707.

34. Saleh F, Shukar-ud-Din S, Soomro N. Serum uric acid as predictor model for preeclampsia. Pak J Surg 26(3): 246-251, (2010). 